\title{
The current situation of Vietnam education
}

\author{
Phu Hop Mai ${ }^{1,2, ~ *, ~ J u n ~ W u ~ Y a n g ~}{ }^{1}$ \\ ${ }^{1}$ College of public management, Hunan Normal University, Changsha, China \\ ${ }^{2}$ School of Political Science, Can Tho University, Vietnam
}

\section{Email address:}

mphop@ctu.edu.vn (P. Mai), yangjwyf@yahoo.com.cn (J. Yang)

\section{To cite this article:}

Phu Hop Mai, Jun Wu Yang. The Current Situation of Vietnam Education. Social Sciences. Vol. 2, No. 6, 2013, pp. 168-178. doi: $10.11648 /$ j.ss.20130206.11

\begin{abstract}
In Vietnam, the workforce is in the "gold" period, it will be the implementing motivations of the strategy socio-economic development. However, with methods of education for so long which do not fit the requirements of the new era, is producing passive "people" who is good at theory but bad at practice. School violence has still occurred; activities of tutors are rampant; the situation of abuse of collection, study, exams are still heavy; negative still exists, living standard of teachers is still difficult. The author's attempt in the paper is to present the achievements and limitations of Practical education policy of Vietnam today. Documents used by the agency's functionality Vietnam and international announced. Through analysis and synthesis authors propose methods intended to correct the weaknesses.
\end{abstract}

Keywords: Vietnam, Education, Crisis

\section{Introduction}

The educational achievements of Vietnam today are a proud achievement due to the open policy. Beside promote internal achievements, international institutions and developed countries have significantly contributed. However, education in Vietnam which is too outdated in comparison with other regional countries and the world, do not meet the needs of development of the society. The education system is much hidden weaknesses from operating mechanism to the curriculum. Vietnam does not have a particular educational philosophy, the phenomenon of commercialization of education, running by economic interests, running by quantity regardless to all practical standards and international experience, the application or unsuccessful applications of the education of developed country; living standards of teachers is too low; phenomenon of qualifications focus, training does not stick with social needs; theoretical lack of practice, it's... the cause of forestry education in crisis. The author's attempt in the paper is to present the achievements and limitations of Practical education policy of Vietnam today. Through analysis and synthesis authors propose methods intended to correct the weaknesses.

\section{Practical Policies and Educational Achievements}

Since 1975 Vietnam has built educational models folding Soviet's one. However, because the level of development of Vietnam was not similar to the Soviet's one, so this model did not promote this effect. Therefore it was changed. Vietnam comes to the education of English-speaking countries such as the U.S, UK, and Australia... In reality, the fact shows spirituality and quickly learning. The spirit itself contributes to the development of education.

With the condition of lacking human resources and facilities, the investment and development in education face with many challenges, while social development needs increasingly require human resources with high quality. Before this situation, the Communist Party of Vietnam has widened and set up open policies to attract domestic and foreign social components to invest in education. Since 2000 , Vietnam has enacted legislation to encourage the commercial presence of foreign educational suppliers according to mechanisms for profit or non-profit, in the form of representative offices, associated units and units with $100 \%$ foreign capital. The positive side of it was already accelerating diversification of education to meet the learning needs and encouraging the inbound study aboard of the learners from high-income families.

Because of trade policies, education is governed by the 
laws of the market; it also becomes the "goods". Education is both a public benefit and as a public service sector, so it should also be referred to as the market. However, this is not ordinary goods, this is specific market. Goods are expressed as books, training programs; curriculum, educational equipment, software, and management experience which are brought to exchange in the market. Or goods are also expressed in the form of labor force of educational managers, teachers... It can be seen that the purposes of these goods will benefit to certain individuals; however, the supreme and final purposes of it are for the whole community, for the development of social equality. And the competition has made education developed more and more.

Vietnam has been aware of that the process of globalization and international integration impacts directly and indirectly on education, while Vietnam is lagged behind many countries in the region and the world. Vietnam has joined the WTO and implemented the General Agreement on Trade in Services (GATS), in which education is recognized as a trade service sector. And Vietnam is gradually boosting international cooperation and educational service market is growing dynamically.

The process of servicing education associated with the process of globalization and international integration of education has changed the educational functions, which was raised to a new level in relation to the other fields of social life - such as economic functions, investment functions, functions to create new social values and social connections, the international competitiveness...; Education is not only pure personnel training and social welfare.

Interference, dialogue, cooperation, competition, struggle between educations makes education of each country to have both ethnic values, and international humanity values. The "win", "loss" of an education is not only in the large or small owning of educational shares, high or low level, but also in adopting, in developing effectively positive and more advanced values of the other education systems of mankind. Understand and promote the values of the nation, take-over selectively the international values to effectively integrate.

Due to changes in the functions and development mechanisms of education associated with higher levels of development of the socio-economy and other fields, education of Vietnam is developing in new trends, such as:

- Popularizing trends.

- Trends in the diversification of forms and methods of education - training, development of distance and online learning, functional and model changes in the base of education and training.

- The trend of globalization, regionalization, integration and cooperation with international competitiveness in education - training increases.

- Education - Training increasingly attached directly causal, more effective with development of socio-economy, science and technology.

- Development mechanism of education and training is increasingly more compatible with the mechanisms of socio-economic development, market mechanisms, and the nature of services and service suppliers of education and training which are more and more increased; innovated methods implementing social welfares in education to improve efficiency.

- Trend to promote socialization, public-private combination of educational development and training is strengthened.

- Education for adult people becomes a growing demand, creating a demand for lifelong learning, the schools with traditional training methods cannot effectively respond.

- Ensure and control the quality of education and training to become society's problems, a content of state management, a national value, a condition for expanding international cooperation.

Vietnam has been aware of these trends and always innovates and modernizes the education system to successfully implement strategic breakthrough "rapid development of human resources, particularly high-quality human resources" in the new period.

On 13/6/2012 the Prime Minister issued Decision No. 711/QD-TTG approved "Education development strategy for 2011-2020". Decision is the basis for reforming comprehensively basic education, improving the structure of national education systems; consolidating, improving teacher training system, innovating basic and comprehensive contents and training methods, implementing preferential policies for the physical and spiritual motivation for teachers and education managers; innovating content, teaching methods, examinations; investigating and evaluating the quality of education; expanding and improving the efficiency of international cooperation in education, developing and application of educational methods of some advanced education systems in the world, in which Vietnam is particularly interested in American education.

To implement this strategy, Vietnam builds up and completes a number of policies for open education. The attention of the whole Party and the peoples, in which the reforms of educational thoughts, and the reforms to attract foreign investment to Vietnam education has now achieved some important results, is ranked by the World Economic Forum 120 previously, but now ranked 69 of 140 surveyed countries [1].

Learning needs of people are met better by the diversity types of school and forms of training; some important results of the strategic objectives are gained (such improving intellectual level, workforce training, fostering talents). Social Policy on Education has been performed better and more efficiently; Quality of education had initial changes; conditions which ensure development of education are boosted.

Looking back at the historical development of education in Vietnam, no one can deny the great achievements that the education sector has been achieved in the past 65 years. If in 1945Vietnam still remained 95\% illiterate people, but in 2010 there were $97.3 \%$ literacy [2]. Not long ago, higher education was reserved for the elite of society to prepare 
them to become a teacher, a scientist and social management, but now this is not the case anymore. Globally, the proportion of college has increased $75 \%$ during the period from 1991 to 2003, particularly in Vietnam; the figure was $600 \%$ [3].

Vietnam has developed a comprehensive education system at all levels in all regions with various types of schools and the number of pupils enrolled at the school is more and more increasing. Higher education are also increasingly expanded in the scope of training, facilities are more and more improved; training programs are gradually renewed. Higher education in Vietnam has met with the world trends which are towards to universalize higher education, on the other hand still remain the elite educational background. The system of vocational schools, education colleges is strengthened. The ethnic schools are expanded, creating the conditions for ethnic children to go to school. Teachers are stronger. In all societies, the interests in education are clearer.

Recognizing clearly the role of the intelligentsia for the development of the country, the Communist Party of Vietnam always pays attention to the intelligentsia and establishes the appropriate policies to unite, to gather, to attract their contributions to the country. Vietnam has built a team of teachers and education administrators crowded with a total of over one million people (about 950,000 teachers, lecturers and over 90,000 management education staffs), with increasingly improved level. To achieve these achievements, besides those policies, one of the solutions to management which is being applied, is division -accumulation credit systems associated with higher education in America.

However, beside the achievements, education still remains hidden weaknesses, if the situation is looked objectively and responsibly at, it is easy to see more and more remote lag of $\mathrm{VN}$ education compared to other countries. The shortcomings are overcome slowly; quality of education is still low, paying more attentions to quantity than quality; phenomenon of commercializing education, inadequacies in choosing careers, works... Education is not really a top national policy.

\section{Practical Education but not Real and Qualifications Focus in Vietnam}

For any country, the human resources are extremely important. And for Vietnam, the workforce is in the "gold" [4] (Representative of the UN Population Fund (UNFPA) evaluated that Vietnam has entered a golden period of population structure with the youngest population group in the country's history: the population is at the age of 10-24 accounted for nearly $1 / 3$ of the population. This review was presented at the press conference published report "State of World Population 2011" held on 27/10) period, it will be the implementing motivations of the strategy socio-economic development. But "Gold population" is not actually gold if educational policies are not appropriate and practical like today.

Vietnam considers that education is as a top national policy and the foundation for the development of the country. However, after many renovations, but so far, besides the educational achievements, Vietnam's education still reveals many limitations. Conclusion No. 51-KL/TW dated 29-10-2012 of the $6^{\text {th }}$ Plenum of the $11^{\text {th }}$ Central Conference on the project "Innovating basic and comprehensive education and training to meet the requirements of industrialization and modernization in the condition of the socialist-oriented socio-economy and international integration "specifies" the education and training of our country is not really a top national policy, the most important motivation for development. Many limitations and weaknesses of education and training which have been raised from Resolutions of the $6^{\text {th }}$ of the $8^{\text {th }}$ Central Conference has not yet resolved basically [5], these achievements are remarkable, but not enough convince to people when some non-educational concerning phenomenon are increased and more public. This shows the great responsibility of every citizen to the development of the country, because education contributes an important part in building the next generation of the future. Never before as now, public opinion, as well as scientists and experts have lost patience in waiting for education and training itself to change the effective methods of education and training. Methods of education for so long which do not fit the requirements of the new era, is producing passive "people" who is good at theory but bad at practice. School violence has still occurred; activities of tutors are rampant; the situation of abuse of collection, study, exams are still heavy; negative still exists, living standard of teachers is still difficult.

In higher education too many problems need to be solved. The quality of the training, problems of continuous or associated training. The foreign educational institutions training in Vietnam ${ }^{1}$. There are many establishments that have been suspended or stripped license to operate in Vietnam, but there are still lots of other facilities that are not only the independent existence but also exist as continuous or associated training to the Vietnam's schools [6]. Most of these institutions are merely for the purpose of economic benefit. The problem of scientific research, the quality of teaching staff and facilities also remain numerous weaknesses.

Vietnam has joined the WTO and implemented General Agreement on Trade in Services (GATS), which recognizes education as a commercial service trade sector. And

\footnotetext{
${ }^{1}$ And with 118 programs of 94 international partners cooperated with 18 universities in the country, the Government Inspectorate of Vietnam also indicates that there are 5 high-ranked universities in the region and around the world. Most of the remaining partners have not been ranked or lower-ranked schools in the country. Meanwhile, tuition of associated training programs with foreign partners is from $\$ 8,000$ to $\$ 10,000$ /course and up to $\$ 13,500$ /course. Conclusion of the Government Inspectorate of Vietnam confirmed that the tuition for students is high, but the quality of education is not commensurate with the contribution level of student.
} 
Vietnam boosts gradually international cooperation and open market of educational services. Therefore, Vietnam's education has more economic functions, and investment functions; and from that there is a sad reality that a division based on significant interests and ideological notions of trivial pragmatic, the pragmatism is that the people who founded it - unexpected theory tools, the real purpose of the pragmatisms who build their own education system to develop knowledge for humans to master themselves. In the education sector in Vietnam, while the autonomy is strengthened to perform the innovation process, beside the managers who promote their roles, dynamic and creative abilities, there are the people who take advantage of loopholes in the policy to attempt illicit profits. They consider education as a common market like type of "demand-supply" market. This is an extremely dangerous activity, when in Vietnam's society, for this reason and other reasons, most people do not consider learning as an understanding demand, they consider learning to get the qualification to pursuit their own interests. Achievement disease, develop the quantity but not focus on the quality. Evils of use illegal diplomas and certificates; phenomenon of "real certificate without studying"; dishonesty in study and examinations, copying essays, dissertations tend to spread, which negatively effect on quality of the training to the young generation's moral and social trust. Phenomenon and trends of choosing majors of young people are easy-to-earning and easy-to-promotion in society leading to unbalancing of human resources. Achievement disease has impacted on the process of teaching, learning, and student assessment as well as education management operation. And this is one of the reasons for making the assessment of education, especially in quality, not reflect essence of problems.

The limitations and weaknesses are the reasons why quality of Vietnam's manpower is very low, so it needs to be improved soon. And according to the survey, $63 \%$ of college graduates are unemployed. In terms of vocational training, unskilled and untrained labors grade 1,2 and 3 accounted for $55 \%$, grade 4,5 accounted for $23.9 \%$, grade 6,7 accounted for $8.4 \%$, labor from vocational college accounted for $11.1 \%$, and graduate and post-graduate university accounted for $1.6 \%$. This suggests that there is a serious imbalance between high-skilled and low-skilled labor. Number of low-skilled workers accounted for too high proportion (55\%), while the number of highly qualified workers grade 6,7 is too low (8.4\%) [7]. From this figure, it shows that Vietnam's education gets mater. And it also explains why Vietnam exports physical labor, contrary to hiring high qualified workers from other countries.

\subsection{Pragmatism in Paying more Attention to Quantity than Quality}

At this present, Vietnam's education fall into severe crisis, especially in higher education, Mr. Thomas J. Valley\& Ben Wilkinson (Harvard University) said that Vietnam's education run after "pragmatic but unrealistic" [8]. History of development socio-economy in the East and Southeast Asia showed close relationship between development and higher education. Although each of the most prosperous countries in the region - South Korea, Taiwan, Singapore and China recently - have developed in the direction of their particular development, but the development of higher education and scientific research is a common concern. Vietnam is facing a golden opportunity in the labor force, but also facing with great challenges. One of the challenges is how to develop the workforce. Vietnam in recent years has promoted the training of the team, but in reality it can be seen that the Vietnam's education now is pragmatic but unrealistic.

The less successful countries in Southeast Asia - Thailand, Philippines, and Indonesia - have shown us. Generally, these countries do not have a qualified higher education, so they could not well-developed modern economies. This does not reveal what is good for the future of Vietnam, because Vietnam's universities are obsolete, even in comparison with the nothing special neighboring countries in Southeast Asia. Table 1 shows the number of documents published by the Science Citation Index Expanded, Thompson Reuters [9].

Table 1: The number of documents from some countries in Asiatic Region has been published and cited in 2011.

\begin{tabular}{|c|c|c|c|c|c|c|c|c|}
\hline & \multicolumn{2}{|c|}{ Country } & \multirow{2}{*}{$\begin{array}{l}\text { Documents } \\
373.756\end{array}$} & \multirow{2}{*}{$\begin{array}{l}\begin{array}{l}\text { Citable } \\
\text { documents }\end{array} \\
365.421\end{array}$} & \multirow{2}{*}{$\begin{array}{c}\text { Citations } \\
177.334\end{array}$} & \multirow{2}{*}{$\begin{array}{l}\begin{array}{l}\text { Self } \\
\text { Citations }\end{array} \\
103.245\end{array}$} & \multirow{2}{*}{$\begin{array}{l}\text { Citations } \\
\text { per } \\
\text { Document } \\
0,47\end{array}$} & \multirow{2}{*}{$\begin{array}{l}\text { H index } \\
353\end{array}$} \\
\hline 1 & $\square$ & $\underline{\text { China }}$ & & & & & & \\
\hline 2 & $\bullet$ & Japan & 115.416 & 108.877 & 94.705 & 34.116 & 0,82 & 602 \\
\hline 3 & 돈 & $\underline{\text { India }}$ & 88.437 & 81.914 & 46.137 & 20.121 & 0,52 & 281 \\
\hline 4 & :o: & $\underline{\text { South Korea }}$ & 60.846 & 57.987 & 47.905 & 15.152 & 0,79 & 309 \\
\hline 5 & $\square$ & $\underline{\text { Taiwan }}$ & 40.234 & 38.302 & 27.871 & 9.251 & 0,69 & 249 \\
\hline 6 & 员 & Malaysia & 18.875 & 18.271 & 8.845 & 4.051 & 0,47 & 116 \\
\hline 7 & 四 & $\underline{\text { Singapore }}$ & 14.511 & 13.684 & 18.365 & 4.620 & 1,27 & 240 \\
\hline
\end{tabular}




\begin{tabular}{|c|c|c|c|c|c|c|c|c|}
\hline & \multicolumn{2}{|c|}{ Country } & \multirow{2}{*}{$\begin{array}{l}\text { Documents } \\
12.870\end{array}$} & \multirow{2}{*}{$\begin{array}{l}\begin{array}{l}\text { Citable } \\
\text { documents }\end{array} \\
12.158\end{array}$} & \multirow{2}{*}{$\begin{array}{c}\text { Citations } \\
11.900\end{array}$} & \multirow{2}{*}{$\begin{array}{l}\begin{array}{l}\text { Self } \\
\text { Citations }\end{array} \\
2.652\end{array}$} & \multirow{2}{*}{$\begin{array}{l}\text { Citations } \\
\text { per } \\
\text { Document } \\
0,92\end{array}$} & \multirow{2}{*}{$\begin{array}{l}\text { H index } \\
268\end{array}$} \\
\hline 8 & 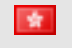 & Hong Kong & & & & & & \\
\hline 9 & 를 & Thailand & 9.760 & 9.173 & 6.418 & 1.512 & 0,66 & 156 \\
\hline 10 & 田 & $\underline{\text { Pakistan }}$ & 8.294 & 7.886 & 4.612 & 1.794 & 0,56 & 101 \\
\hline 11 & $\square$ & Indonesia & 2.741 & 2.651 & 1.575 & 315 & 0,57 & 103 \\
\hline 12 & $\square$ & $\underline{\text { Bangladesh }}$ & 2.197 & 2.114 & 1.106 & 342 & 0,50 & 89 \\
\hline 13 & $\star$ & $\underline{\text { Viet Nam }}$ & 2.130 & 2.038 & 1.457 & 337 & 0,68 & 101 \\
\hline 14 & $\Delta$ & $\underline{\text { Philippines }}$ & 1.350 & 1.282 & 1.631 & 238 & 1,21 & 107 \\
\hline 15 & 10 & Sri Lanka & 859 & 799 & 443 & 78 & 0,52 & 78 \\
\hline
\end{tabular}

The data indicate that the number of international articles published in the country of 90 million people per year is about a number of universities in Thailand. No Vietnam's universities are ranked in the rankings of top 400 [10] universities in the Asia. But the number of professors, doctors in Vietnam is largest number in Southeast Asia (According to statistics of the Ministry of Science Technology, in 2011 Vietnam had 24,300 doctoral and 101,000 masters. Compared to the year of 1996 the average increase of this team is $11.6 \%$ / year in which the number of doctors increased by $7 \%$ / year, the number of master increase by $14 \%$ MSc / year). Mrs. Pham Bich San, Deputy Secretary of Vietnam Union of Science and Technology Associations (VUSTA), stressed in the comments for the science and technology law amended on 18.10.2012 in Hanoi "We have not almost had any scientist who can die for science and is recognized by the international scientific awards"[11].

Vietnam has invested (equivalent to $0.5 \%$ of $\mathrm{GDP}^{2}$ ) for scientific research and technological development. However, scientific researches caused huge waste for society because the scientific works of the school, ministry wasted tens millions of funding for each project, but few projects are applied in reality.

On university systems; According to statistics of the education sector, in the two years 2006-2007, 39 universities have been established, with an average of 20 ones per year. In 4 years, from 2008 to 2011, 45 universities have been established, with an average of 11 per year. And in 5 years, from 2006 to 2011, 84 new universities have been set up and upgraded 51 universities (accounting for 61\%), the establishment of 33 new universities (accounting for 39\%). Currently, Vietnam has 440 universities, colleges, in which there are 77 non-public universities. Each year there are 125 thousands graduates [12]. However, the majority of the labor force is not qualified enough to meet the needs of the economy and society. The surveys conducted by the agencies related to the state showed that $63 \%$ of Vietnam's

\footnotetext{
${ }^{2}$ It is estimated that in 2012 GDP of Vietnam will reach 136 billion USD.
}

graduated students could not find suitable jobs for their expertise.

Events if Intel Company that has struggled to recruit engineers for their manufacturing facility in Ho Chi Minh City is a typical example. When the Company conducted a contest for 2000IT students in Vietnam, there were only 90 qualified candidates. It means that only $5 \%$ of candidates were qualified. And in this group, only 40 candidates have qualified the English language to be able to use. Intel Company recorded that this is the worst results in comparison with other countries where they invested in. At a career fair in Da Nang, Hanoi, there were 1000 participated candidates, but only 5-7 candidates were recruited [13].

Vietnamese and international investors told that the shortage of qualified workers and managers is a major barrier to their expansion.

From the fact, it can be seen that there is a huge gap between the classroom and the job market. So what is the cause of this situation?:

* With the training program which is too focus on theory, practice is not paid much attention $(25 \%$ subjects of university's subjects is theoretical dogma subjects) so students are prepared badly for their future work or improvement of after graduation level.

* The universities currently have no links with enterprise research institutions, they also do not pay attention to what the labor market needs. Professor Pham Minh Hac - Former Minister of Education and Training said: "Obviously, it can be seen that the education has been commercialized a lot compared to the past. The universities and colleges still find every method to enrollment to get students for profit. But the issue of training and jobs for their students after graduation is not much concerned. It can be said that the goal of many universities in our country today is profit rather than purely educational goals. The consequences could be very hard, when the universities run after the immediate benefits, in order to serve their own interests while they ignore the long-term benefits" [14].

* Besides that, today the majority of universities have applied training programs under credit system. However, the facilities, equipment and the number of teachers do not 
increase the quantity and quality to perform this program. The spirit and attitude of student self-study is not high, and the spirit of self-study is cannot be promoted.

* When Vietnam opened the education market and educational needs of peoples are increasingly growing, the series of universities was established. In the non-public newly established universities, because the managers are businessman or "passion in business" the quality of pedagogy and education here is restricted.

* Due to the rules of life, a law always has loopholes and businessman always find out the way to take advantage of gaps in the law. And it can be seen that the non-public universities are mainly concentrated in majors with low practical equipment investment, laboratories such as economics and foreign language... Therefore, while some industry-specific specifications such as automation, process control, agriculture and forestry are hungry for workforce, economic and financial majors are falling into overproduction.

* When the number of university is developed too rapidly, the teachers, equipment, laboratories are not sufficient to supply, so this effect strongly on the quality of training.

Besides that the poor quality of training which also comes from the very basic social reason is "qualification focus" of Vietnam. This disease is manifested pragmatic and harm for the development of education in particular and society in general.

\subsection{Phenomenon of Degree Appreciation Is a Serious Disease for the Vietnamese Society Nowadays}

In fact, the psychology of degree appreciation is itself harmless if it goes with a proper certification mechanism, which reflects the capability of each person through the degree.

The most successful country in pursuing the degree appreciation is Japan. In this country, the employee assessment relies heavily on their degree which really created a strong competition in the society. The employees are scrambling to get the qualified degrees to establish the premise for success. But in Vietnam, this is a different story, in many cases the university degrees are not associated with actual capacity of the holder, and evaluation mechanism does not concern this "compatibility" but only concentrates on the degree.

Degrees are only the premise but the object to assess the development potential and ability of a person, but in fact in Vietnam, they are often regarded as the requisite tool. This shortcoming perception has led to two major problems: Firstly, some people "has real degree but low quality" have opportunities to undertake important positions which is unworthy, Secondly, the opportunities for those who do not have degrees but actually have capability are have been deprived.

In Vietnam, most people think that the best way to accomplish the goals of life is to obtain good university degree; it is like a travel ticket after 12 years of education. This seems to be a big barrier created by parents and the society, which forces their children to try their best to overcome, and many young people do not pass this pressure, leading to the fear and depression feeling, even suicide. It is a painful truth that the parents and managers are struggling to solve. With so many types of degrees, diplomas, certificates, and training levels, over 400 colleges and universities (excluding intermediate schools, vocational centers, and other types of non-formal education up to 659 institutions of district level) has become the huge factory of degree issuance, a kind of "service" to meet the society's needs in the opening period. And that is natural formation according to the principle of supply and demand which has two basic causes.

Firstly, Vietnamese have the psychology of degree appreciation. Currently, every family and person is longing that they themselves or family members could obtain a university degree, even it is also specified in the criteria of the state authorities of district level and education authorities of provincial level. It is actually a type of achievement disease which leads to the fact of redundant teachers and shortage of workers, unemployment, and more dangerous the disease of "actual degree but simulated man" and creates a workforce with professional capacity which does not reflect the requirements of the degrees.

Secondly, the mechanism of employment and promotion is too dependent on degrees, ignoring the scientific recruitment process with 7 steps: Recruitment - selection choosing - probation - fostering - promotion - dismissing. So many provinces "say No with In-service degrees" ${ }^{3}$ which is not the correct answer for manpower recruitment. A full-time degree does not reflect the true capacity of the employee. The process of appointing and promotion for key positions not based on actual capacity, which is based on standard diploma. Therefore, most of the key positions in the period from 2005 onwards had been promoted before they completed the congruence. Apparently during the training time, the work quality and training quality of the leaders was reduced, and ultimately, the outputs had poor quality, which not only occurred during that period but it is also extended to present.

Of course, the problem of evaluating the products of some sectors requires further research of the managers and scientists to obtain the specific identification on the basis of establishing the assessment criteria for contribution quality compatible with the interests in general and the economic benefits in particular to which the employee is entitled. Especially for the non-production sectors such as: scientists, teachers, literary authors, artists... currently there is no standard scale to evaluate their products to be converted into economic value.

In the society, people seriously appreciate educational

3 In many countries, in-service training is practical training system independent, separate from the formal training system, content heavy on practical training, professional services directly. In Vietnam, the program has been built on the basis of systems of formal training. however short training time so of poor quality 
degrees and base primarily on the degrees in recruitment and underestimate the real capacity of individuals. The degree appreciation and practical lifestyle leads to significant impacts on the society:

In 2012, the Vietnamese society concerned about the story of Deputy Minister of Health - Cao Minh Quang and his counterfeiting Ph.D. degree. In the affidavit, the Deputy Minister declared that he was granted the Ph.D. Degree at the University of Uppsala (Sweden), but the functional authorities identified that he never obtained this degree. The Department of Internal Political Security (A83) under the General Department of Security II identified that the University of Uppsala, Sweden only granted the certification of Pharmaceutical Study for Mr. Cao Minh Quang, which is not the Ph.D. degree.

On the mass media, we could easily find articles about the phenomenon of degree buying, point selling, and academic degree selling. Because the positions always go with a degree; therefore, in many cases when a person is promoted, but he does not obtain the qualified degree criteria. He must buy a good degree to validate the promotion and appointment, or to keep the existing position. Therefore the Vietnamese society has the phenomenon: "inflation" of degree holders, but seriously lack of capable managers and entrepreneurs to operate the business and social activities. The phenomenon of "redundant teachers but lack of workers" is probably the typical evidence for the above issue. On the Labor newspaper published on 26/06/2012, there are some figures that we must concern about: "the number of masters, doctors, and internship trainees are double the number of workers level $7 \ldots$ the number of vocational students is lower than one fifth compared to the unification period. In 1991, the budget for vocational training accounts for $8.7 \%$ of the education budget, but since 1996 , this figure has fallen down to $4 \%$ to $4.5 \% \ldots$ and $90 \%$ vocational schools only have their "name" to exist". Sadly, many people express the altitude to consider that issue as a normal thing.

Not until now does the story about the fake degrees appears, in many years ago, when the national economy developed, the people no longer have to worry about "what to eat each meal", they aspire to conquer another target: To have a position in the society. However at "old age, exhausted intelligence" they do not have enough time to study and the ability to obtain a degree in the true sense, they find any way to "obtain" the degree or even a "good " degree, because the average degrees are redundant in this society. Thus, despite economic difficulties, many families try to have their children study abroad. After several years with a degree granted by foreign universities, they could easily apply for positions in state agencies or domestic enterprises.

Due to the degree appreciation, in kindergarten period, the parents find any way to have their children study in granted schools and selected classes, or extra study so that their children could attend a university. Many schools become overloaded; the parents must be queued all night to get a position for their children. The parents are willing to "bribe" so that their children could be arranged at the best class... But in fact, we could not blame the parents because the recruitment which bases on degrees has become popular. In any business or State agency, the recruitment requires degrees, or at least a formal university degree. Those who have more degrees and higher degrees will be preferred. They do not need to know the real capability of the recruited ones, but the input must satisfy sufficient criteria. After the recruitment, the promotion also base on the degrees.

From the degree appreciation, people become to rush... for degrees. If a person has finished the College degree, he will transfer to university training; after university education, they transfer to higher education... with the aim to obtain a sheet of degree which is considered the ticket to pass through the "recruitment doors" easily. That explains why a Deputy Minister also converted a certificate into a "Ph.D degree" to write on his personal card or to write on the curriculum vitae for... majesty.

From story of degrees, we must look back to the quality of education, training, and recruitment in businesses and state agencies. In universities, after every training course, most students graduate with a good or excellent degree, but the number of capable employees among them are not big. We could not blame the businesses and agencies because they are quite shy in the recruitment, because in fact, they are familiar with the notion "University graduates are not so good, even for College graduates...".

Currently, most of employees in the State agencies must have at least a university degree or higher. However many of them work in a different field from what they was trained. And among the employed people, how many percent of them could work in the natural sense. To answer this question, at the first meeting of the Scheme steering committee for promoting the reform of the public regime and civil servant on 25/01/2013, Deputy Prime Minister Nguyen Xuan Phuc stated that "In the state organ, we have $30 \%$ of useless civil servants, because they works with the style "Arrive in the morning and leave in the afternoon" and do not have any work benefit" [15] (Vietnam is having 2.8 million civil servants).

The agencies and units do not pay enough attention to the real capacity appreciation. Just look at each university graduation period, there are hundreds of valedictorians who are invited to work for state agencies, but after a few years, the remaining number is only counted on the fingers.

It is time to seriously reconsider all stages of creating a degree which reflect the true capacity of the respective holder. Then the degree appreciation disease will be reduced.

The lesson of Vietnam is primarily to prepare a social eye, so that the people realize the downsides of degree society, and education is the first authority to take the responsibility for issuing the degrees in the proper scientific process and take responsibility for the degree to meet the true needs of the society.

The law of proportional effects of education on income will be suppressed if the way society is organized labor 
process. If labor management based on qualifications, ability to do the job, job layout to make realistic goals and distribution, remuneration based on performance, quality and effective labor is clearly difficult issues to a degree can take effect. Because the people are not stupid enough to invest in counterfeiting degrees to be discarded when they could not satisfy the job requirements.

\section{Practical in Choosing Occupation and Work Place among Young People Nowadays}

\subsection{The Youth Tend to Choose the Majors Nowadays}

Currently, due to the impact of practical lifestyle, pragmatic pressures, money and degree appreciation, in the education of Vietnam, the youth tend to choose the majors which help them obtain money and promotion after graduation, or easy to study. Meanwhile, they turn their back on the social and humanity majors, agriculture, forestry, and fishery majors. This phenomenon is causing many shortcomings in education and society nowadays such as the imbalance of labor, big waste for the society... The education researchers and social managers are paying much concern about this problem to seek for the solution.

According to statistics of Ministry of Education and Training, in 2011 only $4.44 \%$ of the students attended the social and humanity block, that number in 2012 was $4.43 \%$. There are no statistics on this sector in 2013, but for block C this year in particular the number of registered candidates continues to decrease over the previous year [16].

In Hanoi University of Education in 2012, the number of dossiers for block C (social sectors) was 4,042, but in 2013 this figure drops to 3,306; University of Social Sciences and Humanities, National University - Hanoi also report that the number of dossiers for block $\mathrm{C}$ decreases compared to the previous year.

Hanoi University of Business and Technology received only 49 dossiers for block C among 12,007 dossiers. Mr. Dang Kim Vui, Director of Thai Nguyen University said: In comparison with previous years, the competitiveness in block $\mathrm{C}$ is decreasing; the competitive ratio used to be $1 / 20$ or $1 / 30$, now it is only $1 / 4$ or $1 / 5$.

In the South, Mr. Trieu Tan Tu, Office of Professional Education - Long An Department of Education and Training said that among a total of 28,500 dossiers, there were only 233 dossiers to Ho Chi Minh City University of Social Sciences and Humanities, and only 88 dossiers for block C. Similarly, the Binh Duong Department of Education and Training also said that only they received only 516 dossiers for block $\mathrm{C}$ among the total of nearly 15,700 dossiers here; Dong Nai received 1,400 dossiers for block $\mathrm{C}$ among the total number to over 52,800 dossiers this year ${ }^{2}$. Besides, the young people are also indifferent to the majors such as forestry processing, fisheries, rural development, and agricultural extension, agricultural business, agriculture and forestry engineering, Mechanics of agricultural products and food processing and storage... There is a paradox in Vietnam which is stated in the latest report of the World Bank that Vietnam is the country with agricultural economy; $73.3 \%$ are the rural population, there is a huge demand for jobs in this field, $100 \%$ of graduates from this field could have jobs; however the young people are not keen on this major. Therefore, the workers in the field have very low qualification [17].

According to the report by the Ministry of Education and Training in 2011, among 416 universities and colleges, there were 248 institutions which train economic sectors. The ratio of dossiers for such sectors in 3 years (2009-2011) accounted for nearly $41 \%$ [18] of the total dossiers, while other basic sectors such as agriculture - forestry - fisheries, architecture, and construction only accounted for a few percent. To solve this problem, from the end of 2012, the Ministry of Education and Training has announced that: From 2013 the Ministry stops opening "saturated" majors such as banking finance, business administration, and accounting..., do not open new universities which train these majors. However, students of these majors not only face difficulties due to job application but also subject to higher tuition fees. Ministry of Education and Training states that in the near future, it will reduce the support from state budget for the training majors, which are capable of socialization such as economics, finance, and law... For these majors, the Ministry will allow institutions to identify the tuition fees, and each institution will itself manage the training costs from the tuition fees, incomes from scientific researches, technology transfer, and other socialization sources. It is estimated that the tuition fees for these sectors will increase, to ensure $50 \%-90 \%$ of the training costs from 2012 to 2016 . But this is only a temporary solution through administration, the root of the problem is economic prioritization psychology, if this psychology still exists, the phenomenon will continue.

The reason why this phenomenon is becoming popular in Vietnam:

Indifference to block $\mathrm{C}$ seems to be an irresistible trend when the majority of opinions showed the inadequacies in the teaching and studying of Literature - History - and Geography which is repeated and in forms and gradually loses the interest for students. On The Pioneer 20/5 [19], Ms. Nguyen Nhu Huong, a Literature teacher in Pham Hong Thai High School, Hanoi acknowledged that only Literature attracts the students because some of them attend block D. The students do not have interest in the two subjects History and Geography. They only study them if these two subjects are chose as graduation subjects. The only benefit to students is that the competitive ratio in block $\mathrm{C}$ will decrease, which means that the door to university will be wider. However, if students choose Block $\mathrm{C}$ for this reason, the lecture halls will only be the temporary shelter for a generation of students who loose the root of knowledge. Consequently, the labor market will receive employees with the "fake" knowledge and they will have to spend much time 
to study the basic skills again (typing, selling, tailoring, and accounting...) which could totally be trained I colleges, intermediate schools, and vocational schools. Another trend for these graduates, they will seek for shelters after graduation into the state agencies, where the salary is low but stable; after a period of time they will be among the $30 \%$ of useless public servants who bring umbrellas to workplace in the morning and bring umbrellas home in the afternoon. This vicious circle continues to rotate, creating hindrance for the human resources; this is a burden on the budget and a huge waste.

Some comments stated that the reason why young people "turn their back" on the social sciences and humanities is the bad impression from the high school education. There is an implicit distinction between main and auxiliary subjects. The math, physics, chemistry, biology, and foreign languages are always carefully taught by the teachers. On the other hand, literature, history, and geography seem to be taught briefly until the end of the books, and teachers do not care about what the students have acquired. The heavy curriculum makes students even more afraid of social subjects. Therefore, there are few students choosing to study these subjects in university.

In addition, many students consider social sector the "second class" major they find it harder to find jobs, and receive low payment. Some young people say: the graduates from social sciences and humanities could only find jobs in state agencies, research institutes; they must do theoretical work, and work within the framework like a machine rather than creation. Workers of this field must work in remote areas and have little opportunities of promotion. Social sector only nominal without money, while the current society appreciates economic conditions and money as the key targets.

Other reason is that many businesses and banks open, thus there are many job opportunities, high salary and bonus... The psychology attracts the students, so that most of them choose economic majors. As a chain reaction, year by year the students always choose economic majors as a secure solution and ignores their true passion and hobby.

On the other hand, in the society there is a phenomenon of disdain social science and Humanity majors. So that many parents know their children's limited capacity, but still force them to study in economic majors. Because students of economics are often highly appreciated and respected, while in the social sector, there are many strange majors for high school students such as psychology, Southeast Asia study... In addition, there are many other reasons why the social sector is forgotten such as the narrowing scale of literature, history, geography, philosophy, and anthropology..., and there is unreasonable salary allocation among the sectors...

Social science and humanity sectors have been warned about the lack of students in very long time ago. The trend of young people in choosing careers is affected by social movement which appreciates economic factors. The students selects according to the majority. That choice creates more secured psychological rather than following their hobbies, passions, and forte. Notably, the students recognize the weaknesses of social science and humanity sector such as lack of investment and improper incentives. They also criticize the heavy training style basing too much on books at the secondary and high school levels. The bad impression at the high school level increases their fear of social science and humanity sector. Operation of the society focuses too much on the economy, the stronger people are those who are dominant in money, which affects them in the form of "money could buy anything" "The rich are powerful ones", "the money is justice" not those with knowledge and culture. The slow innovation of teaching methods and curriculum of social and the humanity subjects in high school level, the heavy operation of the society promoting materialistic values are causing strong impact on the trend of the choosing carrier among the young people. This is not their fault.

The vocational education in schools is ignored or implemented perfunctorily. In most high schools, the first concern is how to help the students study well and the ratio of graduated students. They do not concern about what the students study and where they work after the graduation day. Not all schools have proper concern about that problem. Meanwhile, the awareness of students and their parents about choosing career is very one-sided. The students' psychology of career choosing is a game of chance, choosing the career in the imposition of the parents, according to time, "hot" jobs, or jobs easy to make money... and forget one thing: whether these carriers suit their capacity, interest, or self-conditions.

The decrease in block $\mathrm{C}$ registration means that the candidates are turning their back on the social science majors. This is easy to be seen even in high school level, most students are not interested in social science division; many schools do not have this division. Large number of students studying in social science division and block $\mathrm{C}$ are from rural areas and they have with average academic performance. So the examination scores of block $\mathrm{C}$ are lower and lower, thus the human resources for social science not only reduced, but also less qualified.

The consequences of this problem have been warned by many experts. Assoc. Prof. Dr. Nguyen Kim Son, Deputy Director of the National University, Hanoi suggested that: "Students nowadays pay more attention to and follow such majors as technology, engineering, economics, finance, and banking... because of greater job opportunities and higher income. It means that Vietnamese people, especially young people highly appreciate the benefits and they are more pragmatic. There are many who believe that the economic growth in recent years happened so powerful, it requires large human resources, forming tornado that sweeps the workforce in to that economy, eclipsing the social science and humanity sectors. This is also partly true, but it is not the normal rule of development process. The economy is developed; the people's lives are improved, then the social science, humanity, and arts must also have more power to be developed rather than faded. The economic development 
that created the crisis in the society and humanities is an abnormal development" [20].

When we talk about social sciences and humanities, it means that we talk about politics - society, moral, thought, and culture of a people. The social sciences are not only the cultural and social foundation but also the orientation subjects for the development of a country. Therefore, the social science and humanity subjects should be at the forefront to orient the society. If we do not appreciate and do not have sufficient investment, the consequences would be extremely serious.

Report on the status of labor supply and demand by the Ministry of Labor, Invalids and Social Affairs which has been proposed to the government shows that Vietnam's labor market has labor surplus and uneven development, particularly the relation of labor supply and demand among the regions, areas, and industries, which is leading to the seriously unbalanced situation with approximately $60 \%$ of graduates who are not working in the trained fields [21].

Many young people are practical in carrier choosing, they choose according to the movement. When they graduate, many young people do not work in the right profession. That means wastes for the state, waste for the students themselves, and waste for their families. Because they do not choose the right career and they do different jobs after graduation, then they have wasted the majors which they are trained.

\subsection{Along with Practical Psychology in Carrier Orientation and Choosing Is the Pragmatic Issue in Workplace Choosing after Graduation among the Young People}

Along with the degree appreciation of the families, clan, and young students, most rural young people desire to attend a "University", after graduation from University or College, they do not want to return home but seek for a job in urban areas, they are not eager to work in the rural areas, which leads to a shortage of workforce in the rural areas to participate in the production and business activities, to maintain political security and social order, safety, cultural traditions; besides many workers rush to the cities, so that in many rural areas, there are only the elderly and children.

In fact, this trend is unstoppable. This is the natural law of the developing countries and can not be avoided. The workforce line drawn to the cities in the economic perspective has solved the jobs for workers but caused the social consequences. Families of farmers are separated; the sustainability of the families is gone. Many of major labors abandon their farms for cities, which causes unbalance in population and the agriculture can not develop.

The Vietnamese government implemented the resolution on three crop agriculture; on the one hand to solve the jobs in order to limit the village leaving trend; on the other hand to facilitate rural development. However in fact what the farmers are entitled are not equal to their contribution. That is one of the reasons why the young people not interested in the rural areas.

The point to concern is that most students do not return the rural areas after graduation but still remain in the cities. In have a job here, they accept to work for a different field and to deal with many obstacles. Therefore, in Vietnam, $60 \%-70 \%$ of the workforces need to be trained for further knowledge and skills [22]. This is a huge waste for the society.

The survey results by Institute for Educational Research under National University of Education, Ho Chi Minh City showed that $75 \%$ of students desire to live in the cities [23], to have a job to "develop their dreams and to seek for opportunities" and many people are willing to abandon their trained profession in universities.

According to survey data of the Vietnamese Institute of Psychology, $36.2 \%$ of interviewed young people say that they did not want to live and work agricultural jobs, but to do something with high income.

Although the unemployment rate in the cities is increasing, many high students rush from the provinces to the cities and try to stay in the cities after graduation. Working in different profession is a now reality, this is one of the reasons why the start-ups of the young people are harder, waste of time and money for training in universities.

This causes a paradox that the remote areas are lack of human resources with knowledge and skills while many students are still in unemployment situation in the cities.

There are many reasons for this situation: It is easier to find jobs in cities, the income is higher, and the living environment is more pleasant than rural areas. The cities have the facilities and means to access information, and there are more opportunities.

Another reason is that many young students after studying in the cities are infected by the urban lifestyle. They compare and find living in urban areas more comfortable with full services and facilities, but the life in rural areas does not have sufficient utilities and facilities serving their modern lives. So many graduates stay in the cities to continue living in the city rather than to promote their profession.

Many people assume that a large number of people due to the practical lifestyle become fear, lack of striving, afraid of difficulties, poor voluntary spirit... The personal interests and social practices make many young people choose their own way of life; they do not see or deliberately not see the value that can benefit the society. They seek for values that satisfy their direct personal demand and consider it the reflection living values and standards of development measurement for individuals and groups of people. Here the personal interest has passed the interest of the community, the collective spirit, and even covered their lifestyle. Therefore, few graduates are willing to volunteer to remote areas for teaching or become doctors in their commune/ward. "Few young people join in the labor transfer and assignment, but they avoid their duties or not ready" [24]. Just a small number of young people express that dark side. But the society must direct, persuade, and encourage young people to quickly rule out the pragmatic lifestyle. This is not only the responsibility of the Youth Union but also the 
responsibility of the entire society, so that the personal needs could be satisfied, ensuring the social characteristics, which forms the personal responsibility and a sense of community, not for today but for the future, not only for themselves but also for the community and society.

\section{Limited Remedies}

To solve this crisis, a number of urgent issues to be implemented in Vietnam as follow:

1) Vietnam should change the policies for teachers, salary policy, housing and working conditions soon. The Vietnamese Government should create all conditions for teachers and educational administrators to live well with their wages. Therefore, they could wholeheartedly work, improve their expertise. They will not be worried about their living conditions and join in extra teaching, extra work, and the negative issues in education will not occur.

2) Examination and quality evaluation will be implemented seriously, which is associated with the subject division at High School level and completion of credit regime at undergraduate level.

3) Emphasize quality and standards instead of chasing the quantity despite standards; connect training with the real social needs. Invest in equipment, laboratories, training to improve qualifications of teaching staffs and educational managers.

4) Reform the management (especially financial management), overcoming the bureaucracy, increase the professionalism and accountability, prevent wastefulness and corruption in the sector.

\section{References}

[1] Phạm, V. L. 2011. Về một số vấn đề nổi cộm trong giáo dục đào tạo hiện nay. Báo cáo tại kỳ hợp Quốc hội Việt Nam.

[2] Viet Nam. 2010. General statistics office.

[3] World Development Indicators. 2005. Participation in education.

[4] UNFPA. 2011. Báo cáo tình trạng dân số thế giới năm 2011, Hà Nội-Việt Nam.

[5] Đảng cộng sản Việt Nam. 2013. Tài liệu nghiên cứu Nghị quyêt Hội nghị lần thứ 6 , Ban Chấp hành Trung ương khóa XI, Hà Nội, pp. 253.

[6] Văn, N. C. 2013. Đổi mới giáo dục - Kỳ vọng vào năm con rắn.

http://www.giaoduc.edu.vn/news/van-de-su-kien-665/doi-m oi-giao-duc-ky-vong-vao-nam-con-ran-202847.aspx.
[7] Lê, V. C. 2013.Tap Chí Cộng Sản. Một số ý kiến về đổi mới chính sách giáo dục và đào tạo đội ngũ trí thức.

[8] Thomas J. Vallely and Ben Wilkinson. 2008. Vietnamese higher education crisis and response. Memorandum Higher Education Task Force, Page 2- 11.

[9] http://scimagojr.com/countryrank.php

[10] Thomson reuters. 2013. Aisa Univer sity rankings 2013 top 100.

http://www.timeshighereducation.co.uk/world-university-ra nkings/2012-13/world-ranking/region/asia.

[11] Phạm, B. S. 2012. Đóng góp ý kiến cho luật Khoa học công nghệ sửa đổi. Hà Nội-Viet Nam.

[12] Việt Nam. 2013. General statistics office.

[13] Phạm, M, H. 2012. Thất vọng và kỳ vọng vào giáo dục Việt Nam. Báo Giáo dục Việt Nam.

[14] Xuân, T. 2013. Giáo dục và “vòng xoáy” của thương mại hóa. Pháp Luật Và đời sống.

http://phapluatxahoi.vn/2013041009563214p1001c1051/gia o-duc-va-vong-xoay-cua-thuong-mai-hoa.htm.

[15] Nguyễn, X. P. 2013. Bài phát biểu tại cuộc họp thứ nhất Ban chỉ đạo Đề án đẩy mạnh cải cách chế độ công vụ, công chức. Hà Nội-Viêt Nam.

[16] Bộ Giáo dục và Đào tạo, 20/05/2013. Cục Khảo thí và Kiểm định chất lượng.

[17] Nguyễn, L. D. 2008. Những vấn đề cấp bách đối với nông nghiệp nước ta. Vietsciences.

[18] Bộ giáo dục và đào tạo. Báo cáo 14/2/2012.

[19] Báo, X. L. 2013. Khối C thất sủng: điều tất yếu. http://www.xaluan.com/modules.php?name=News\& file=arti cle\&sid $=609686$

[20] Nguyễn, K. S. 2012. Khoa học xã hội \& Nhân văn: Từ thực tiễn xã hội đến giáo dục đại học. Đại Học Quốc gia Hà Nội, $256, \mathrm{p} 7$.

[21] Đan, T. 2011. Sinh viên trước thách thức làm việc trái ngành. Giáo dục và thời đại.

http://www.gdtd.vn/channel/2762/201111/Sinh-vien-truoc-th ach-thuc-lam-viec-trai-nganh-1955168/02/11/2011.

[22] Bộ Lao động - Thương binh và Xã hội Số: 133/BC-LĐTBXH $15 / 12 / 2009$. Thực trạng cung - cầu lao động và những giải pháp.

[23] Mạnh, M. 2010. Sinh viên ngoại tỉnh: Quyết tâm bám trụ chốn đô thi.

http://www.vietnamplus.vn/Home/Sinh-vien-ngoai-tinh-Quy et-tam-bam-tru-chon-do-thi/20107/54183.vnplus

[24] Lê, P. P. L. 2013. Truyền lửa cho thế hệ trẻ ngay từ gốc. Sài Gòn Giải Phóng. 